\title{
SUVREMENA DEMOGRAFSKA OBILJEŽJA PODGORJA
}

Ivo Turk

Nenad Pokos

Institut društvenih znanosti Ivo Pilar

Marulićev trg 19

HR10000 Zagreb

ivo.turk@pilar.hr

nenad.pokos@pilar.hr

Nikola Šimunić

Institut društvenih znanosti Ivo Pilar

Područni centar Gospić

Trg Stjepana Radića 4/1

HR 53000 Gospić

nikola.simunic@pilar.hr
UDK: 314.6(497.5 Podgorje)

Pregledni članak

Ur.: 2017-02-20

Podgorje obuhvaća prostor hrvatske jadranske obale u podnožju Velebita. Adminsitrativno gledano, istraživanjem su obuhvaćena naselja Grada Senja, te općina Karlobag i Starigrad, koja svojim teritorijem participiraju na obali Jadranskog mora. Promatrani je prostor podijeljen između Ličko-senjske (Grad Senj i Općina Karlobag) i Zadarske županje (Općina Strarigrad). Podgorje ima vrlo negativna demografska obilježja. Ukupna depopulacija traje, s iznimkom jednog međupopisja (1981. - 1991.), kontinuirano od 1910. godine kada je zabilježen maksimum naseljenosti (16 782 stanovnika). U sljedećih se sto godina broj stanovnika skoro prepolovio. Prema najnovijim popisu stanovništva iz 2011. godine Podgorje je imalo samo 8894 stanovnika. Prirodna depopulacija je u Podgorju prisutna dugi niz godina što vrlo negativno utječe na demografske prilike. Starenje stanovništva je u vrlo uznapredovalom stadiju. Godine 1971. indeks starenja iznosio je 58, dok je prema posljednjem popisu iz 2011. vrijednost toga demografskog pokazatelja porasla na čak 187,8 .

Razlozi ovakvog nepovoljnog demografskog stanja su kompleksni. Fizičkogeografska obilježja nepovoljno su u prošlosti utjecala na razvoj (krški reljef s mnogo strmih oblika, jaka bura). Danas se Podgorje nalazi u zoni preklapanja nodalno-funkcionalnih područja Rijeke, kojoj gravitira njegov sjeverni dio te Zadra, kojem gravitira njegov južni dio. Izgradnjom autoceste Zagreb - Split i planiranom izgradnjom autoceste ili brze ceste Rijeka - Žuta Lokva, Podgorje će se u biti naći u svojevrsnoj prometnoj izolaciji, što neće povoljno djelovati na demografske i ekonomske tokove. 
Unatoč položaju na jadranskoj obali koji nudi dobru mogućnost razvoja turizma, s iznimkom Starigrada, gdje je polazišna točka za izlete u NP Paklenica, ta djelatnost u Podgorju nije znatnije razvijena, što nepovoljno utječe na demografske prilike.

Ključne riječi: Podgorje, ukupna depopulacija, prirodna depopulacija, starenje stanovništva, prometna izoliranost

\section{Uvod}

Podgorje je specifičan dio hrvatske jadranske obale koji se prostire ispod Velebita. Postoji više tumačenja njegove prostorne definicije. U ovome se radu pod pojmom Podgorje smatraju naselja u sastavu Grada Senja, te općina Karlobag i Starigrad koja svojim administrativnim teritorijem izlaze na Jadransko more. Ovakva se definicija Podgorja čini najprimjerenijom jer isključuje one prostore koji su reljefno viši, pa ne mogu biti "pod gorom". Dio Podgorja koji je u sastavu Grada Senja i Općine Karlobag pripada Ličkosenjskoj, dok dio u sastavu Općine Starigrad pripada Zadarskoj županiji. Naselja uključena u ovo istraživanje u sastavu Grada Senja su: Bunica, Jablanac, Klada, Lukovo, Pijavica, Prizna, Senj, Starigrad, Stinica, Sveta Jelena, Sveti Juraj, Volarice i Vrataruša. Istraživana naselja u sastavu Općine Karlobag su: Barić Draga, Cesarica, Karlobag, Konjsko, Lukovo Šugarje, Staništa, Sušanj Cesarički i Vidovac Cesarički. U istraživanje je uključena i cijela Općina Starigrad s naseljima: Seline, Starigrad (Paklenica) i Tribanj.

Podgorje je specifično po svojim prirodnim karakteristikama koje obiluju kontrastima. Sam prostor Velebita je jako raznolik i njegova se lička padina znatno razlikuje od primorske. Klima Podgorja je pod velikim utjecajem Velebita, a taj je utjecaj nepovoljan za naseljavanje. Kao vrlo nepovoljan klimatski element treba istaknuti buru, koja može onemogućiti gotovo sav promet u Podgorju i koja osjetno pridonosi povećanju osjeta hladnoće, što je osobito uočljivo zimi. Cijeli se promatrani prostor nalazi u zoni krškog reljefa. ${ }^{1}$ Podgorje je dio hrvatske jadranske obale koji ima najnepovoljnije demografske pokazatelje. U međupopisju od 2001. do 2011. Podgorje predstavlja najveći kontinuirani prostor na hrvatskoj jadranskoj obali s prisutnom ukupnom depopulacijom, pa je ono ujedno stoga i problemska regija u sastavu hrvatskoga jadranskog primorja. Izgradnjom autoceste Zagreb - Zadar - Split, koja prolazi kroz Liku, i planiranom izgradnjom autoceste ili

${ }^{1}$ V. ROGIĆ, 1958, 53-116. 


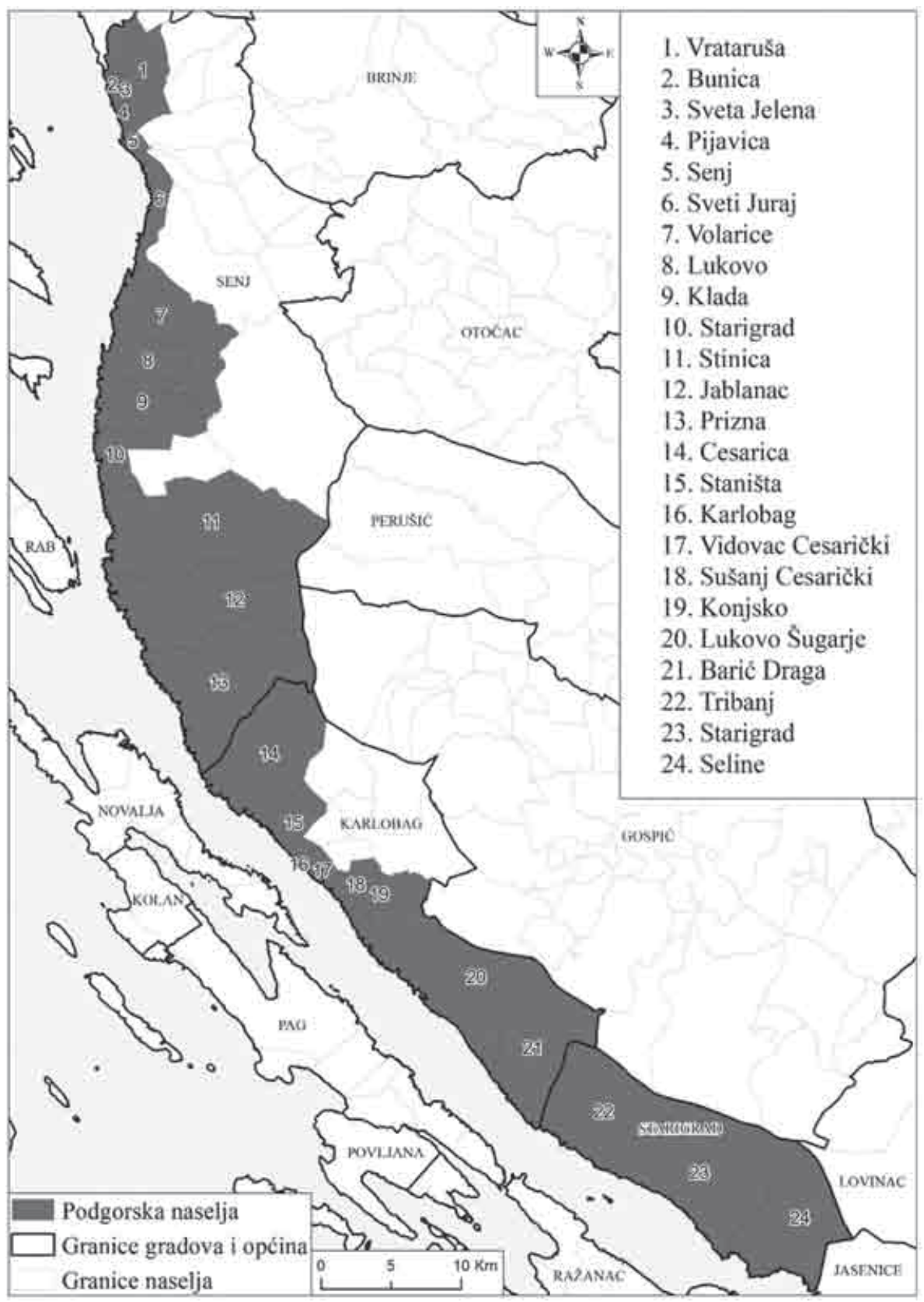

Sl. 1. Teritorijalni obuhvat Podgorja 
brze ceste od Rijeke do Žute Lokve, Podgorje ostaje izvan glavnih prometnih tokova iako njime prolazi Jadranska magistrala. Senj i Podgorje su zapravo oduvijek bili po strani od glavnih prometnih pravaca duž istočne jadranske obale. ${ }^{2}$ Razlozi zbog kojih trase autocesta zaobilaze Podgorje treba tražiti $\mathrm{u}$ nepovoljnim prirodno-geografskim obilježjima (nepovoljne reljefne i klimatske značajke). Neuključivanje u glavne prometne tokove (prometna izoliranost) ne ide u prilog revitalizacije Podgorja, no s obzirom na položaj uz more i očuvan okoliš može se reći da postoje dobri preduvjeti za razvoj. Podgorje je najizrazitiji primjer ruralne periferije, a povezano s tim i razvojnoproblemskog područja, u litoralnom pojasu Hrvatske. Takva njegova obilježja determinira su udaljenošću tog izduženoga i rijetko naseljenog dijela priobalja od razvijenijih žarišta socio-gospodarskog razvoja, s jedne, te funkcionalnom i demografskom nerazvijenošću njegovih malobrojnih središnjih naselja $\mathrm{s}$ druge strane. ${ }^{3}$

\section{Popisno kretanje broja stanovnika}

Ako se razmotri razdoblje od početka 20. stoljeća do danas, primjetno je da je maksimum naseljenosti Podgorja bio davne 1910. godine kada su u tamo živjela 16782 stanovnika. Od tada je skoro kontinuirano prisutan trend pada broja stanovnika. Indeks promjene broja stanovnika u razdoblju od 1900. do 2011. iznosio je 55,7 dok je za razdoblje od 1910. (maksimum naseljenosti) do 2011. njegova vrijednost bila 53. Pad broja stanovnika zabilježen je u svim međupopisjima u promatranom razdoblju, osim u onom od 1981. do 1991. kad je zabilježen minimalan i zanemariv porast broja stanovnika. On je uzrokovan većim popisivanjem stanovništva u inozemstvu 1991. godine. Naime, prema popisima stanovništva, broj stalnog stanovništva Podgorja popisanog u inozemstvu bio je 1981. - 505; 1991. - 756 i 2001. - 524. Primjetan je osjetno veći broj takvog stanovništva 1991. u odnosu na prethodni i sljedeći popis. Posebno zabrinjava pad broja stanovnika u najnovijem razdoblju nakon 1991. godine kada je indeks promjene broja stanovnika iznosio 83,9.

${ }^{2}$ V. ROGIĆ, 1952, 47-64.

${ }^{3}$ D. HUSANOVIĆ-PEJNOVIĆ, 2010, 119-142.

${ }^{4}$ Postoje brojne metodološke razlike između pojedinih popisa stanovništva zbog kojih su zapravo ti rezultati neusporedivi. Ipak, u nedostatku drugih izvora za proučavanje stanovništva, navedeni su popisni rezultati smatrani mjerodavnima. 


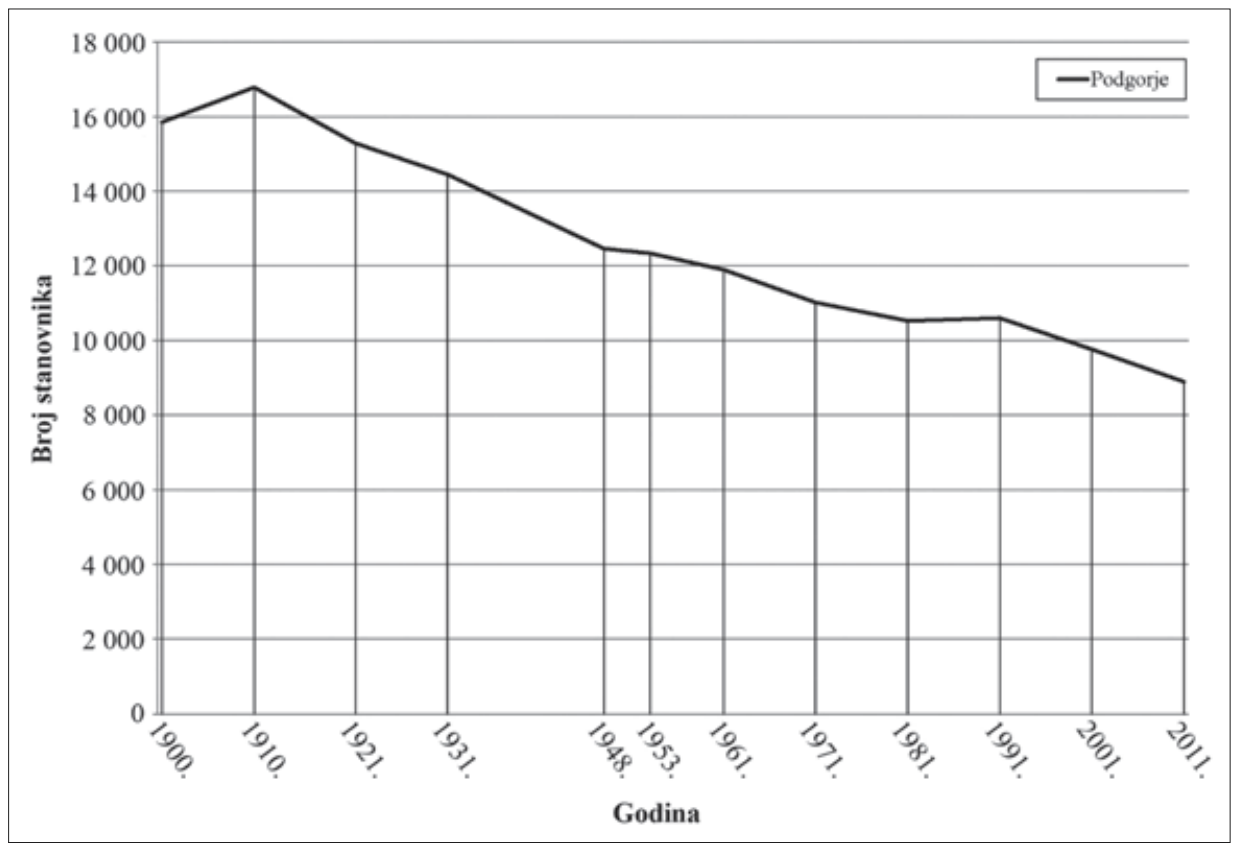

S1. 2. Popisno kretanje broja stanovnika u Podgorju 1900. - 2011., izvor: www.dzs.hr (19.12.2016.)

Tab.1. Popisno kretanje broja stanovnika u Podgorju 1857. - 2011. ${ }^{4}$

\begin{tabular}{|c|c|c|c|}
\hline Popisne godine & Podgorje ukupno & Bazni indeks $(1900 .=100)$ & Lančani indeks \\
\hline 1900. & 15979 & 100 & - \\
\hline 1910. & 16782 & 105 & 105 \\
\hline 1921. & 15281 & 95,6 & 91,1 \\
\hline 1931. & 14452 & 90,4 & 94,6 \\
\hline 1948. & 12459 & 78 & 86,2 \\
\hline 1953. & 12337 & 77,2 & 99,0 \\
\hline 1961. & 11895 & 74,4 & 96,4 \\
\hline 1971. & 11018 & 69 & 92,6 \\
\hline 1981. & 10527 & 65,9 & 95,5 \\
\hline 1991. & 10598 & 66,3 & 100,7 \\
\hline 2001. & 9759 & 61,1 & 92,1 \\
\hline 2011. & 8894 & 55,7 & 91,1 \\
\hline
\end{tabular}

Izvor: www.dzs.hr (19.12.2016.) 
Tab. 2. Broj stanovnika Podgorja 1900., 2001. i 2011. po naseljima (prikazana od sjevera prema jugu)

\begin{tabular}{|l|c|c|c|c|c|}
\hline \multirow{2}{*}{ Naselje* } & \multicolumn{3}{c|}{ Broj stanovnika } & Indeks promjene & Indeks promjene \\
\cline { 2 - 6 } & 1900. & 2001. & 2011. & $2011 . / 1900$. & $2011 . / 2001$. \\
\hline Vrataruša & 480 & 262 & 374 & 77,9 & 142,7 \\
\hline Senj & 3182 & 5491 & 4810 & 151,2 & 87,6 \\
\hline Sveti Juraj & 704 & 692 & 599 & 85,1 & 86,6 \\
\hline Volarice & 1022 & 112 & 86 & 8,4 & 76,8 \\
\hline Lukovo & 448 & 36 & 36 & 8,0 & 100,0 \\
\hline Klada & 500 & 33 & 39 & 7,8 & 118,2 \\
\hline Starigrad & 578 & 11 & 15 & 2,6 & 136,4 \\
\hline Stinica & 1345 & 105 & 73 & 5,4 & 69,5 \\
\hline Jablanac & 914 & 118 & 83 & 9,1 & 70,3 \\
\hline Prizna & 718 & 56 & 45 & 6,3 & 80,4 \\
\hline Cesarica & 672 & 144 & 123 & 18,3 & 85,4 \\
\hline Staništa & 212 & 10 & 6 & 2,8 & 60,0 \\
\hline Karlobag & 737 & 510 & 468 & 63,5 & 91,8 \\
\hline Vidovac Cesarički & 123 & 63 & 56 & 45,5 & 88,9 \\
\hline Sušanj Cesarički & 157 & 13 & 12 & 7,6 & 92,3 \\
\hline Konjsko & 222 & 7 & - & - & - \\
\hline Lukovo Šugarje & 632 & 79 & 68 & 10,8 & 86,1 \\
\hline Barić Draga & 410 & 124 & 125 & 30,5 & 100,8 \\
\hline Tribanj & 1160 & 338 & 267 & 23,0 & 79,0 \\
\hline Starigrad (Paklenica) & 912 & 1100 & 1140 & 125,0 & 103,6 \\
\hline Seline & 737 & 455 & 469 & 63,6 & 103,1 \\
\hline
\end{tabular}

* Prikazana su samo naselja koja su bila statistički samostalna za vrijeme provođenja popisa 1900. i 2001. Naselja koja su izdvojena u međupopisju 2001. - 2011. (Bunica, Pijavica i Sveta Jelena) prikazana su u sklopu naselja Vrataruša čiji su dijelovi bili do 2001.

Izvor: www.dzs.hr (19.12.2016.)

Razmotre li se popisi stanovništva iz 1900. i 2011. uviđa se da su jedino naselja Senj i Starigrad (Paklenica) zabilježili porast broja stanovnika. Razmotri li se popisno kretanje broja stanovnika u naselju Senj, koje je brojem stanovnika najveće u Podgorju, uviđa se da je situacija osjetno različita nego s Podgorjem gledanim u cjelini ili po teritorijalnim sastavnicama.

Naselje Senj u razdoblju nakon Drugog svjetskog rata bilježi kontinuirani porast broja stanovnika do 1991. godine kada je zabilježen maksimum naseljenosti (5998 stanovnika). Od tada je u naselju Senj prisutan kontinuirani pad broja stanovnika. Prema najnovijem popisu stanovništva iz 2011. naselje Senj je imalo 4810 stanovnika što predstavlja smanjenje od 19,8\% u odnosu na maksimum naseljenosti iz 1991. Ovakvo se stanje može 
objasniti činjenicom da je Senj jedino urbano naselje u Podgorju, te koje je u razdoblju bivše Jugoslavije bilo općinsko središte. To znači da je Senj imao određeni centralitet u prostoru Podgorja što je pozitivno utjecalo na tamošnje demografske prilike. S druge strane u ovakvim okolnostima je ruralna okolica Senja imala ulogu negativnog razvojnog pola Podgorja, gdje je prisutna ukupna depopulacija, dijelom i zbog migracije u Senj (migracija selo - grad na lokalnoj razini). Nekadašnja je Općina Senj gravitirala prema Rijeci i nalazila se u Zajednici općina Rijeka. ${ }^{5}$ Ustrojem Županija taj je prostor ušao u sastav Ličko-senjske županije.

Naselje Starigrad (Paklenica) je sjedište istoimene općine. Drugo je naselje po broju stanovnika u Podgorju prema popisu stanovnika iz 2011. Te su činjenice pozitivno utjecale na demografske prilike, no najpozitivniji utjecaj na demografske prilike u ovom naselju ima turizam koji je u najvećoj mjeri povezan s Nacionalnim parkom Paklenica. ${ }^{6}$ Uz to, Starigrad je i sjedište današnje istoimene općine, što također pozitivno utječe na demografske prilike jer se i na takav administrativni način generiraju centralne funkcije koje pridonose demografskom razvoju.

Sva su ostala naselja zabilježila pad broja stanovnika, dok je Konjsko ostalo bez stanovnika u međupopisju 2001.-2011. godine. Uz spomenuto izumrlo naselje, čak devet naselja bilježi indeks promjene broja stanovnika manji od 10, što samo po sebi svjedoči koliko su nepovoljne demografske prilika u Podgorju. Najveći pad broja stanovnika bilježe periferna naselja. Može se primijetiti da od naselja koja su zabilježila pad broja stanovnika, manji pad imaju veća naselja i ona koja se nalaze u njihovoj blizini. Dobar su primjer naselja u blizini Senja pa tako na primjer za Sveti Juraj, koji je ujedno i treće naselje po broju stanovnika u Podgorju prema popisu iz 2011., indeks promjene iznosi 85,1, a za Vratarušu 77,9. Jasno je da je centralna uloga koju Senj ima u prostoru uvjetovala ovakvo stanje.

Naselje Seline ${ }^{7}$ koje se nalazi južno od Starigrada (drugog naselja po broju stanovnika u Podgorju) zbog sličnih procesa kao i u slučaju Senja bilježi manje smanjenje broja stanovnika (indeks promjene 63,6). Jasno je da je i blizina Zadra pozitivno utjecala na relativno manje smanjenje broja stanovnika u ovome dijelu Podgorja.

${ }^{5}$ Z. KLARIĆ, 2016, 29-57.

${ }^{6}$ Nacionalni park Paklenica je drugi najstariji nacionalni park u Hrvatskoj. Proglašen je 19.10.1949., nekoliko mjeseci nakon proglašenja Nacionalnog parka Plitvička jezera.

${ }^{7}$ Seline su prema popisu stanovništva iz 2011. četvrto naselje po broju stanovnika u Podgorju. 


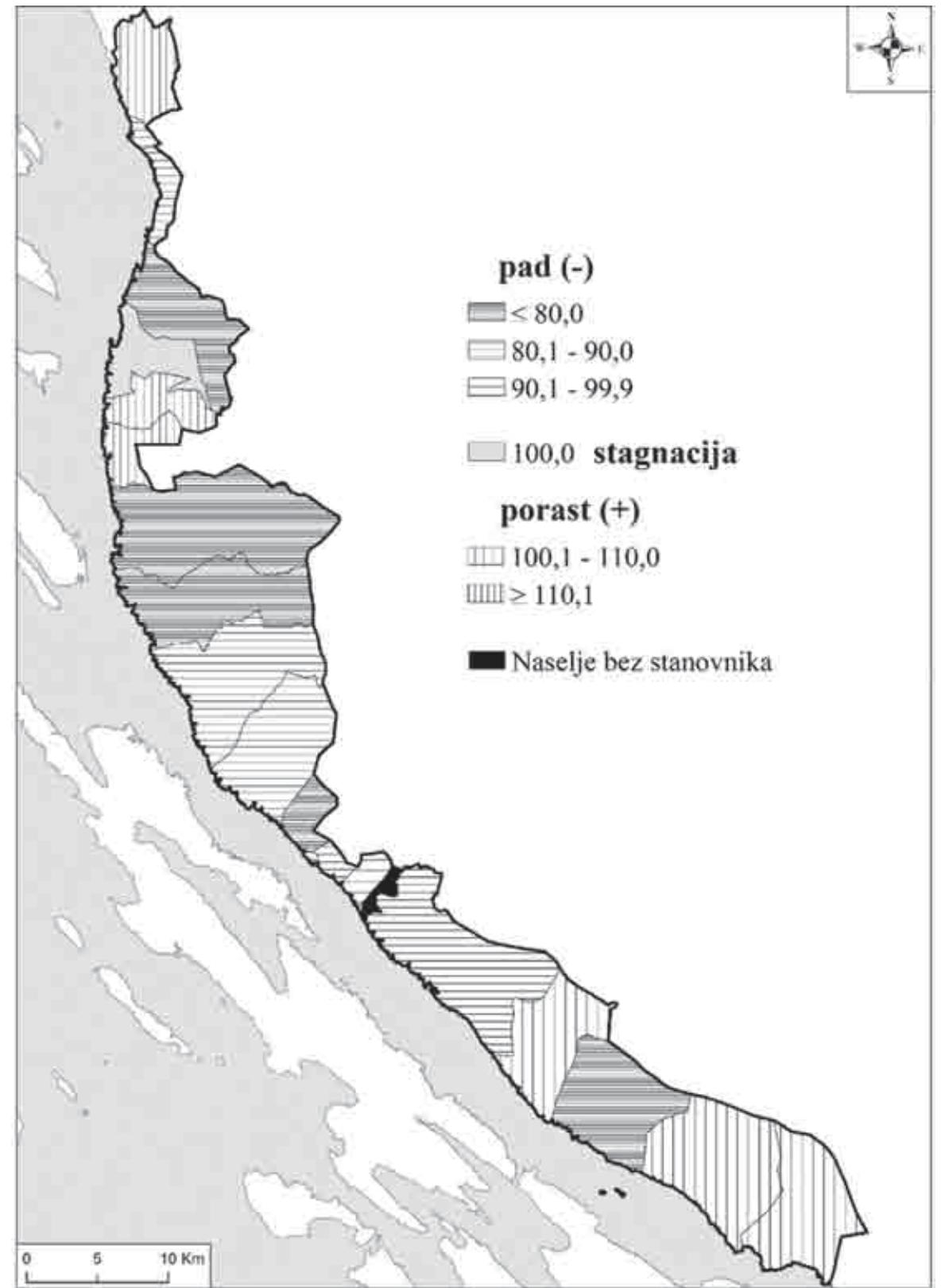

S1. 3. Indeksi promjene broja stanovnika podgorskih naselja 2011./2001., izvor: www.dzs.hr (19. 12. 2016.) 


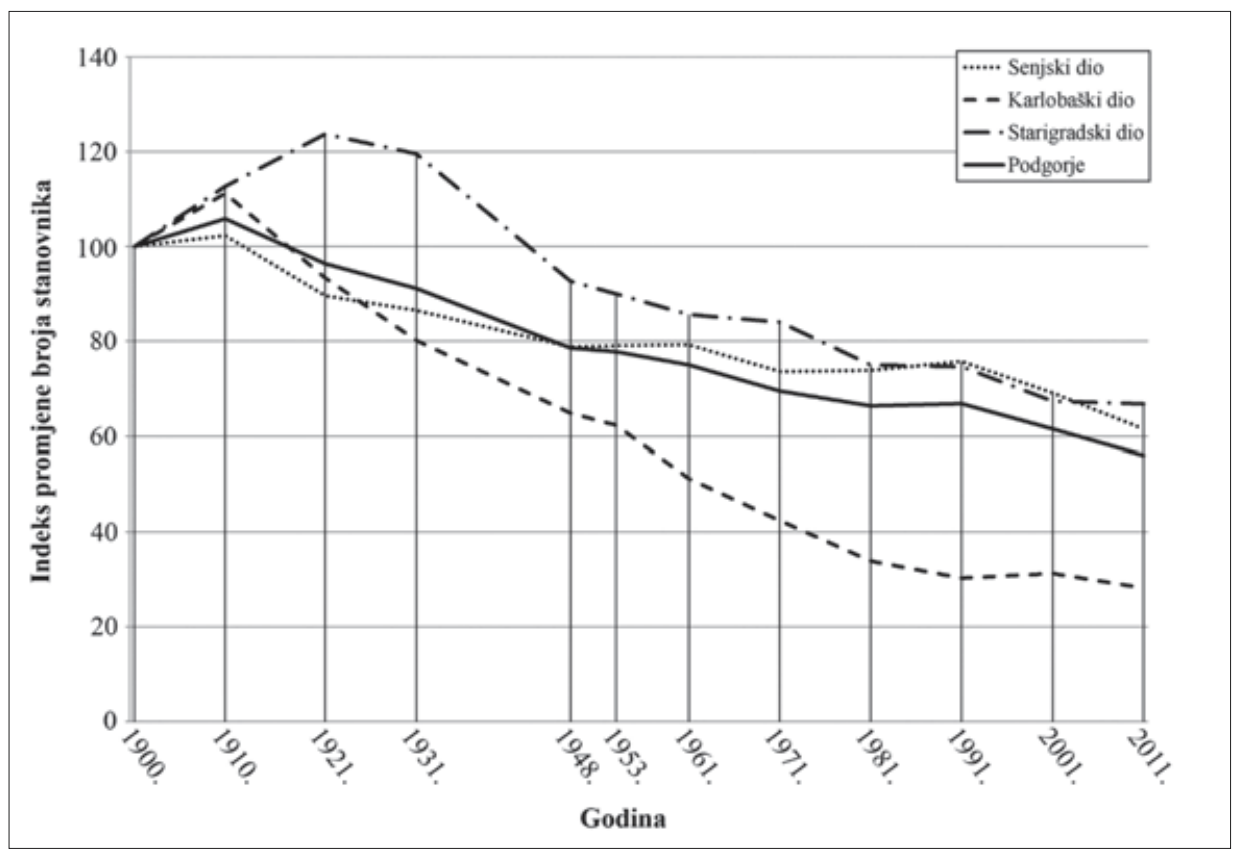

Sl. 4. Kretanje broja stanovnika Podgorja po teritorijalnim cjelinama 1900. - 2011., izvor: www.dzs.hr (19. 12. 2016.)

Naselje Karlobag ${ }^{8}$ koje je općinsko središte također ima nešto manji indeks promjene broja stanovnika $(63,5)$. Susjedno naselje (južno) Vidovac Cesarički bilježi indeks promjene 45,5 što se najvjerojatnije može povezati s relativno pozitivnim utjecajem centraliteta Karlobaga.

Ako se razmotri kretanje broja stanovnika u posljednjem međupopisju, uviđa se da najveći broj naselja bilježi pad broja stanovnika. Takvih je čak 13 naselja dok je jedno (Konjsko) u ovom razdoblju izumrlo. Najnepovoljniji indeks promjene, ne računajući naselje Konjsko, zabilježen je u naseljima Staništa, Stinica i Jablanac. Naselje Staništa ima prema popisu stanovništva iz 2011. samo 6 stanovnika, pa smanjenje s 10 na 6 stanovnika u ovom međupopisju temeljeno na relativnom pokazatelju izgleda vrlo značajno iako u apsolutnom broju smanjenje iznosi samo 4 stanovnika. Nije poznato zašto je prisutan tako izraženi pad broja stanovnika u dva preostala spomenuta naselja. Nasuprot tome, najveći porast broja stanovnika bilježi Vrataruša, točnije naselja izdvojena iz

\footnotetext{
${ }^{8}$ Karlobag je peto naselje po broju stanovnika u Podgorju.
} 
Tab. 3. Kretanje ukupnoga broja stanovnika Podgorja 1971. - 2011. po cjelinama

\begin{tabular}{|l|c|c|c|c|c|c|}
\hline \multirow{2}{*}{ Cjelina } & \multicolumn{5}{|c|}{ Broj stanovnika } & $\begin{array}{c}\text { Indeks promjene } \\
(1971 .-2011 .)\end{array}$ \\
\cline { 2 - 7 } & 1971. & 1981. & 1991. & 2001. & 2011. & \\
\hline senjski dio & 7367 & 7390 & 7580 & 6916 & 6160 & 83,6 \\
\hline karlobaški dio & 1290 & 1030 & 921 & 950 & 858 & 66,5 \\
\hline starigradski dio & 2361 & 2107 & 2097 & 1893 & 1876 & 79,5 \\
\hline
\end{tabular}

Izvor: www.dzs.hr (19. 12. 2016.)

nje (Bunica, Pijavica i Sveta Jelena), te Starigrad (Senj) i Klada. Pretpostavlja se da porast broja stanovnika spomenutih novoizdvojenih naselja koja su ranije potpadala pod Vratarušu ima veze s razvojem turizma i blizine Senja. Povećanje broja stanovnika Starigrada (Senj) i Klade prikazano relativnim pokazateljem izgleda značajno iako ono to u stvarnosti nije zbog male demografske baze.

Razmotri li se indeks promjene broja stanovnika teritorijalnih cjelina Podgorja, odnosno dijelova Podgorja koji pripadaju Gradu Senju te općinama Karlobag i Starigrad, uviđa se da sve teritorijalne cjeline bilježe pad broja stanovnika. U razdoblju nakon Prvog svjetskog rata senjski i starigradski dio Podgorja imaju manje intenzivan pad broja stanovnika od Podgorja u cjelini, dok karlobaški dio ima intenzivniji pad. To se može objasniti perifernim položajem i prometnom izoliranošću tog dijela Podgorja.

U razdoblju od 1971. do 2011. najveći pad bilježi karlobaški dio Podgorja (indeks promjene 66,5) što se može objasniti njegovim perifernim položajem u odnosu na najveće naselje Senj i na relativno veliku udaljenost od Zadra, kojem gravitira južni dio Podgorja. Starigradski dio Podgorja bilježi manji pad broja stanovnika (indeks promjene 79,5). Razlog tome je relativno velika važnost turizma u starigradskom dijelu Podgorja koji je usko povezan s već ranije spomenutim Nacionalnim parkom Paklenica. Turizam je generirao ekonomski razvoj i otvaranje radnih mjesta koja su donekle ublažila depopulacijske procese. Uz to, ovaj je dio Podgorja najbliži Zadru, ${ }^{9}$ što omogućava i dnevnu migraciju stanovništva prema tom regionalnom centru. Senjski dio Podgorja bilježi najmanje smanjenje broja stanovnika (indeks promjene iznosi 83,6). To je ujedno i najnaseljeniji dio Podgorja. Već je spomenuto da je centralna uloga Senja u ovom prostoru najviše pridonijela nešto manjem intenzitetu depopulacije u ovoj podgorskoj teritorijalnoj cjelini.

\footnotetext{
${ }^{9}$ Starigradski dio Podgorja pripada Zadarskoj županiji i sukladno tome gravitira Zadru.
} 
Može se zaključiti da je Podgorje prostor izražene dugotrajne depopulacije, s time da njezin intenzitet nije jednak u svim njegovim dijelovima. Depopulacija je intenzivnija u manjim ruralnim perifernim naseljima, dok je manje intenzivna u većim naseljima, posebice sjedištima gradova/općina.

\section{Prirodno kretanje stanovništva}

Prirodno kretanje stanovništva podrazumijeva dinamiku rođenih i umrlih. Ono je izrazito važan pokazatelj demografske dinamike jer se u njegovim sadašnjim obilježjima očitavaju demografski tokovi iz prošlosti, a sadašnji indikatori prirodnoga kretanja u značajnoj mjeri determiniraju buduće demografske procese. U Podgorju su pokazatelji prirodnog kretanja stanovništva nepovoljniji od Hrvatske promatrane u cjelini, ponajprije zato što se proces prirodne depopulacije (višak umrlih nad rođenima - prirodni pad) javio ranije.

U Podgorju je prirodni pad prvi put zabilježen davne 1972. godine, dok je u razdoblju 1975.-1981., 1983. te 1987. godine zabilježena blaga pozitivna demografska dinamika. Od 1988. nadalje bilježen je prirodni pad s tendencijom sve većeg produbljivanja. Za usporedbu, u Hrvatskoj se isti proces prvi puta javio 1991. godine i od tada kontinuirano traje.

Dinamika živorođenih bilježi kontinuirani pad u promatranom razdoblju. Tijekom sedamdesetih godina prošlog stoljeća u Podgorju se prosječno godišnje rađalo oko 126 djece. U razdoblju nakon 2011. taj se broj prepolovio i sada iznosi oko 62 djeteta. Maksimalan broj živorođenih u promatranom je razdoblju zabilježen 1971. godine kada je iznosio 153. Minimalni je je broj zabilježen 2014. i iznosio je samo 48 (indeks promjene 2014./1971. iznosi 31,4). Najveće naselje u Podgorju, Senj, istih je godina zabilježio maksimalan i minimalan broj živorođenih. Godine 1971. taj je broj iznosio 92, a 2014. pao na svega 25 (indeks promjene 2014./1971. je 27,2). Ovi podatci zorno prikazuju razmjere demografske krize u Podgorju. Naznake poboljšanja situacije se ne uočavaju. Naprotiv, izgledno je daljnje smanjenje broja živorođenih.

Razmotre li se teritorijalne sastavnice Podgorja, primjetno je da je najmnogoljudnija teritorijalna sastavnica ona koja pripada Gradu Senju. Ta teritorijalna sastavnica ima najsličnija obilježja prirodnog kretanja stanovništva kao Podgorje gledano u cjelini. Prirodni pad broja stanovnika prisutan je kontinuirano od 1988. godine do danas i tijekom sljedećih ranijih godina: 1973., 1974., 1984. i 1986., a tijekom svih ostalih promatranih godina je zabilježen prirodni priraštaj. 
Tab. 4. Prirodno kretanje stanovništva u Podgorju (1971. - 2014.)

\begin{tabular}{|c|c|c|c|}
\hline Godina & Živorođeni & Umrli & Prirodna promjena \\
\hline 1971. & 153 & 128 & 25 \\
\hline 1972. & 115 & 118 & -3 \\
\hline 1973. & 124 & 131 & -7 \\
\hline 1974. & 107 & 109 & -2 \\
\hline 1975. & 119 & 109 & 10 \\
\hline 1976. & 124 & 96 & 28 \\
\hline 1977. & 125 & 106 & 19 \\
\hline 1978. & 121 & 102 & 19 \\
\hline 1979. & 139 & 130 & 9 \\
\hline 1980. & 130 & 115 & 15 \\
\hline 1981. & 144 & 126 & 18 \\
\hline 1982. & 116 & 122 & -6 \\
\hline 1983. & 142 & 106 & 36 \\
\hline 1984. & 116 & 131 & -15 \\
\hline 1985. & 126 & 133 & -7 \\
\hline 1986. & 124 & 125 & -1 \\
\hline 1987. & 122 & 115 & 7 \\
\hline 1988. & 108 & 115 & -7 \\
\hline 1989. & 106 & 126 & -20 \\
\hline 1990. & 122 & 157 & -35 \\
\hline 1991. & 100 & 148 & -48 \\
\hline 1992. & 111 & 134 & -23 \\
\hline 1993. & 95 & 163 & -68 \\
\hline 1994. & 111 & 124 & -13 \\
\hline 1995. & 99 & 128 & -29 \\
\hline 1996. & 124 & 161 & -37 \\
\hline
\end{tabular}




\begin{tabular}{|c|c|c|c|}
\hline 1997. & 92 & 150 & -58 \\
\hline 1998. & 82 & 126 & -44 \\
\hline 1999. & 79 & 123 & -44 \\
\hline 2000. & 69 & 139 & -70 \\
\hline 2001. & 69 & 140 & -71 \\
\hline 2002. & 74 & 118 & -44 \\
\hline 2003. & 64 & 124 & -60 \\
\hline 2004. & 62 & 108 & -46 \\
\hline 2005. & 72 & 140 & -68 \\
\hline 2006. & 68 & 132 & -64 \\
\hline 2007. & 59 & 131 & -72 \\
\hline 2008. & 71 & 122 & -51 \\
\hline 2009. & 55 & 123 & -68 \\
\hline 2010. & 82 & 131 & -49 \\
\hline 2011. & 66 & 122 & -56 \\
\hline 2012. & 69 & 134 & -65 \\
\hline 2013. & 67 & 125 & -58 \\
\hline 2014. & 48 & 144 & -96 \\
\hline
\end{tabular}

Izvor: Tablogrami vitalne statistike (1971. - 2014.), DZS, Zagreb

Tab. 5. Broj živorođenih u Podgorju po karakterističnim razdobljima

\begin{tabular}{|c|c|c|}
\hline Razdoblje & Broj živorođenih & Prosječno živorođenih godišnje \\
\hline 1971. -1980. & 1257 & 125,7 \\
\hline 1981. -1990. & 1226 & 122,6 \\
\hline 1991. -2000. & 962 & 96,2 \\
\hline 2001. -2010. & 676 & 67,6 \\
\hline 2011. -2014. & 250 & 62,5 \\
\hline
\end{tabular}

Izvor: Tablogrami vitalne statistike (1971. - 2014.), DZS, Zagreb 


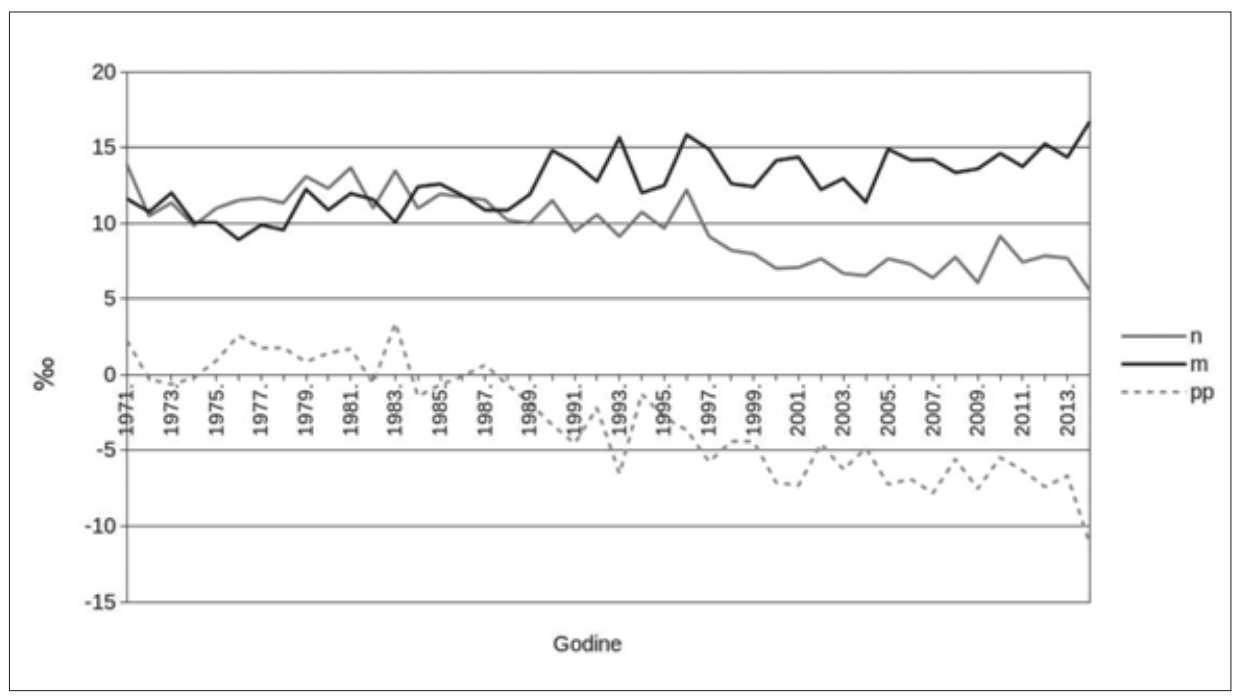

Sl. 5. Stope prirodnog kretanja stanovništva u Podgorju 1971. - 2014., izvor: Tablogrami vitalne statistike (1971. - 2014.), DZS, Zagreb

Starigradski dio Podgorja ima osjetno povoljnija obilježja prirodnog kretanja stanovništva. U ovome dijelu Podgorja prirodni pad broja stanovnika traje kontinuirano od 2005. godine, dok su se između 1971. i 2005. izmjenjivala razdoblja prirodnog priraštaja i pada broja stanovnika ${ }^{10}$. Kao što je već ranije napominjano starigradski, tj. najjužniji dio Podgorja turistički je najrazvijeniji zbog povezanosti s Nacionalnim parkom Paklenica. Ta činjenica i blizina Zadra pozitivno su utjecala na demografske prilike, pri čemu prirodno kretanje stanovništva nije iznimka.

Najnepovoljnije pokazatelje prirodnog kretanja stanovništva ima karlobaški dio Podgorja, a razlog je već ranije spominjana prometna izoliranost. U cijelom promatranom razdoblju (od 1971. do 2014.) prisutan je prirodni pad broja stanovnika s iznimkom 1981. godine kad je jedino zabilježen prirodni priraštaj.

Nepovoljna obilježja prirodnog kretanja stanovništva u Podgorju ne nude optimističnu sliku za budućnost. Proces prirodne depopulacije posljedica je smanjenja ukupnog broja stanovnika i demografskog starenja, što predstavlja ograničavajući čimbenik ekonomskog razvoja.

${ }^{10}$ U starigradskom dijelu Podgorja prirodni je priraštaj zabilježen sljedećih godina: 2004., 1999., 1995., 1994., 1992., 1990., 1988., 1986., 1983., 1978., 1977., 1976., 1975., 1974., 1973. i 1971. Nulta razina prirodne promjene je zabilježena 1989., 1987. i 1985. godine. 
Tab. 6. Populacijska dinamika u Podgorju i tipizacija općeg kretanja stanovništva (1971. - 2011.)

\begin{tabular}{|l|c|c|c|c|}
\hline Međupopisje & 1971. - 1981. & 1981. - 1991. & 1991. - 2001. & 2001. - 2011. \\
\hline $\begin{array}{l}\text { Popisna promjena broja } \\
\text { stanovnika }\end{array}$ & -491 & 71 & -839 & -865 \\
\hline $\begin{array}{l}\text { Prirodna promjena broja } \\
\text { stanovnika }\end{array}$ & 112 & -47 & -440 & -589 \\
\hline Migracijska bilanca & -603 & 118 & -399 & -276 \\
\hline $\begin{array}{l}\text { Tip općeg kretanja } \\
\text { stanovništva }\end{array}$ & $\mathrm{E}_{3}$ & $\mathrm{I}_{2}$ & $\mathrm{E}_{4}$ & $\mathrm{E}_{4}$ \\
\hline
\end{tabular}

Izvor: www.dzs.hr (19.12.2016.); Tablogrami vitalne statistike (1971. - 2014.), DZS, Zagreb

\section{Migracijska bilanca i opće kretanje stanovništva}

Migracijska bilanca predstavlja razliku između popisnog i prirodnog kretanja stanovništva. Načelno, ona je dobar pokazatelj migracijskih kretanja, no u Hrvatskoj njezina vrijednost nije pouzdana jer su se različiti popisi provodili po različitim metodologijama. Najveće su metodološke razlike između popisa iz 1991. i onog iz 2001. jer se do tada korišten de iure princip zamijenio takozvanim de facto principom koji je obuhvaćao samo prisutno stanovništvo. Ukratko, rezultati različitih popisa stanovništva zapravo nisu međusobno usporedivi, no oni se unatoč tome koriste i smatraju mjerodavnima jer ne postoje drugi izvori za proučavanje stanovništva.

Iz tablice 6 vidljivo je da je popisna promjena u Podgorju bila negativna $u$ međupopisju od 1971. do 1981., u sljedećem je međupopisju ona bila pozitivna, a u iduća dva međupopisja ponovno je bila negativna. S druge strane prirodna promjena bila je pozitivna samo u međupopisju 1971. - 1981., a u svim ostalim međupopisjima povećava se trend porasta negativnosti.

Migracijska je bilanca negativna u svim međupopisima, osim u onome od 1981. do 1991. kada je zabilježena njezina pozitivna vrijednost od 118 stanovnika. Taj podatak treba uzeti s rezervom jer je poznato da je u popisu te godine zabilježen veći broj popisivanja stanovništva u inozemstvu. S obzirom na vrijednost prirodnog kretanja stanovništva, jasno je da je temeljem ovih podataka došlo do imigracije u Podgorje, a posljedice te imigracije se teško primjećuju $\mathrm{u}$ prostoru. U ovome se slučaju najvjerojatnije radi o fiktivnoj imigraciji (popisivanju "inozemaca" i popisivanju u kućama za odmor - vikendicama). $\mathrm{S}$ obzirom na to da $\mathrm{u}$ migracijama sudjeluje najčešće mlađe stanovništvo $u$ povoljnoj demoreproduktivnoj dobi, očekivati je da bi u slučaju imigracije 
porastao natalitet i da bi došlo do smanjenja razine ostarjelosti. Naprotiv, indeks starenja se u Podgorju u razdoblju od 1981. do 1991. povećao sa 68,6 na 82,5, pa se s pravom sumnja na fiktivnu imigraciju.

Tipizacija općeg kretanja stanovništva po metodologiji M.A. Friganovića (1990.) ukazuje na dominaciju emigracijskih (egzodusnih) tokova u populacijskoj dinamici. U prvom promatranom međupopisju (1971. - 1981.) zabilježen je tip $E_{3}$ čije je obilježje izrazita depopulacija. U sljedećem međupopisju (1981. - 1991.) je zabilježen imigracijski tip $\mathrm{I}_{2}$ čije je obilježje regeneracija imigracijom. I ovdje, kao i pri objašnjavanju migracijske bilance, valja izraziti sumnju u vjerodostojnost ovih podataka jer stvarni učinci spomenute imigracije nisu vidljivi u prostoru, a proces demografskog starenja se kontinuirano nastavio. $U$ daljnja dva međupopisa zabilježen je najnepovoljniji tip općeg kretanja stanovništva $\mathrm{E}_{4}$ ' čije je obilježje izumiranje stanovništva. $\mathrm{S}$ obzirom na prisutne trendove, izgledno je da će se nepovoljni demografski procesi nastaviti i u budućnosti, što će dodatno pogoršati već postojeću krajnje nepovoljnu demografsku sliku ovog prostora.

\section{Starenje stanovništva u Podgorju}

Starenje stanovništva jedan je od najvećih demografskih problema u Hrvatskoj. Starenjem stanovništva gubi se demoreprodukcijski potencijal što dovodi do pada nataliteta, a spomenuti proces starenja stanovništva predstavlja i veliki ekonomski problem jer je poznato da starije stanovništvo troši više sredstava iz državnog proračuna nego što u njega uplaćuje (za zdravstvenu skrb, mirovine). Kada indeks starenja ${ }^{11}$ premaši vrijednost od 40, smatra se da je započeo proces starenja stanovništva (Wertheimer-Baletić, 1999.). Popisni rezultati iz 1971. prvi su put pokazali da je stanovništvo Hrvatske ušlo u proces starenja jer je tada indeks starenja iznosio 47,2. Od tada je vrijednost indeksa starenja kontinuirano rasla, a prema posljednjem popisu stanovništva iz 2011. ona prvi put premašuje vrijednost od 100, što znači da je u ukupnoj populaciji Hrvatske bilo više starog nego mladog stanovništva. Spomenute je godine indeks starenja iznosio 115. Ovakva je situacija krajnje nepovoljna i ne nudi mogućnost za poboljšanje postojećeg stanja.

Stanje vezano za starenje stanovništva u Podgorju je nepovoljnije od onog u Hrvatskoj razmatranoj u cjelini. Proces starenja stanovništva u Podgorju započeo je ranije i imao je intenzivniji tijek.

\footnotetext{
${ }^{11}$ Omjer broja starih ( $\geq 60$ godina) i mladih ( $\leq 19$ godina) pomnožen sa 100 .
} 
Tab. 7. Odabrani pokazatelji sastava stanovništva Podgorja prema dobi i spolu prema popisima stanovništva (1971. - 2011.)

\begin{tabular}{|c|c|c|c|c|c|c|c|}
\hline Pokazatelji & 1971. & 1981. & 1991. & 2001. & 2011. & $\begin{array}{c}\text { Indeks } \\
\text { promjene } \\
2011 . / 2001 \text {. }\end{array}$ & $\begin{array}{c}\text { Indeks } \\
\text { promjene } \\
2011 . / 1971 .\end{array}$ \\
\hline Koeficijent feminiteta & 1087,5 & 1030,7 & 1014,5 & 1030,1 & 1026,0 & - & - \\
\hline Broj stan. $\leq 19$ god. & 3600 & 2856 & 2508 & 2009 & 1480 & 73,7 & 41,1 \\
\hline $\begin{array}{l}\text { Koeficijent mladosti } \\
(\%)\end{array}$ & 32,7 & 27,1 & 23,7 & 20,6 & 16,6 & - & - \\
\hline Broj stan. $\geq 60$ god. & 2088 & 1961 & 2070 & 2581 & 2779 & 107,7 & 133,1 \\
\hline $\begin{array}{l}\text { Koeficijent starosti } \\
(\%)\end{array}$ & 19,0 & 18,6 & 19,6 & 27,1 & 31,3 & - & - \\
\hline Indeks starenja & 58,0 & 68,7 & 82,5 & 128,5 & 187,8 & - & - \\
\hline Broj stan. $\leq 14$ god. & 2607 & 2017 & 1888 & 1402 & 1048 & 74,8 & 40,2 \\
\hline $\begin{array}{l}\% \text { predradni } \\
\text { kontingent }\end{array}$ & 23,7 & 19,2 & 17,8 & 14,4 & 11,8 & - & - \\
\hline $\begin{array}{l}\text { Broj stan. } 15-64 \\
\text { god. }\end{array}$ & 6930 & 6785 & 7071 & 6425 & 5746 & 89,4 & 82,9 \\
\hline$\%$ radni kontingent & 62,9 & 64,5 & 66,7 & 65,8 & 64,6 & - & - \\
\hline Broj stan. $\geq 65$ god. & 1431 & 1658 & 1439 & 1886 & 2100 & 111,3 & 146,8 \\
\hline $\begin{array}{l}\% \text { postradni } \\
\text { kontingent }\end{array}$ & 13,0 & 15,8 & 13,6 & 20,0 & 23,6 & - & - \\
\hline Broj žena $\leq 14$ god. & 1263 & 957 & 909 & 683 & 503 & 73,6 & 39,8 \\
\hline $\begin{array}{l}\% \text { predfertilni } \\
\text { kontingent }\end{array}$ & 22,0 & 17,9 & 17,0 & 13,8 & 11,2 & - & - \\
\hline $\begin{array}{l}\text { Broj žena } 15-49 \\
\text { god. }\end{array}$ & 2678 & 2538 & 2337 & 2203 & 1773 & 80,5 & 66,2 \\
\hline$\%$ fertilni kontingent & 46,7 & 47,5 & 43,8 & 44,5 & 39,4 & - & - \\
\hline Broj žena $\geq 50$ god. & 1770 & 1811 & 1975 & 2041 & 2228 & 109,2 & 125,9 \\
\hline $\begin{array}{l}\text { \% postfertilni } \\
\text { kontingent }\end{array}$ & 30,8 & 33,9 & 37,0 & 41,2 & 49,5 & - & - \\
\hline Bodovi ostarjelosti ${ }^{12}$ & 83,5 & 78,5 & 74 & 63,5 & 55,5 & - & - \\
\hline $\begin{array}{l}\text { Tipizacija } \\
\text { ostarjelosti }^{13}\end{array}$ & $\begin{array}{c}3 \\
\text { (starost) }\end{array}$ & $\begin{array}{c}3 \\
\text { (starost) }\end{array}$ & $\begin{array}{c}3 \\
\text { (starost) }\end{array}$ & $\begin{array}{l}5 \text { (vrlo } \\
\text { duboka } \\
\text { starost) }\end{array}$ & $\begin{array}{l}5 \text { (vrlo } \\
\text { duboka } \\
\text { starost) }\end{array}$ & - & - \\
\hline
\end{tabular}

Izvor: Popis stanovništva i stanova 1971., Stanovništvo, Pol i starost - I deo, rezultati po naseljima i opštinama, Knjiga VIII, Savezni zavod za statistiku, Beograd, 1973.; Tablogrami popisa stanovništva iz 1981., DZS, Zagreb; Popis stanovništva, domaćinstava, stanova i poljoprivrednih gospodarstava 31. ožujak 1991., Stanovništvo po spolu i starosti po naseljima, dokumentacija 882, Zagreb, 1994.; www.dzs.hr (19.12.2016.)

\footnotetext{
${ }^{12}$ Prema metodologiji I. Nejašmića iz 2003.

${ }^{13}$ Isto kao i pozivna bilješka 8 .
} 
Vrijednosti koeficijenta feminiteta ukazuju na veću brojnost ženskog stanovništva. U starijim je populacijama to normalno jer žene u prosjeku žive duže od muškaraca. Teško je objasniti zašto je koeficijent feminiteta opadao do 1991. godine, a stanovništvo je bilo zahvaćeno intenzivnim procesom starenja. Jedino je moguće pretpostaviti kako je tome razlog veća emigracija ženskog stanovništva. Nakon 1991. godine koeficijent feminiteta je porastao, no posljednji popis iz 2011. godine prikazuje njegovu manju vrijednost nego što je to bilo 2001. Imajući u vidu povećanje razine ostarjelosti, teško je naći pravi razlog za ovakvo stanje.

Koeficijent mladosti koji označava postotak mladog stanovništva $(\leq 19$ godina) u ukupnoj populaciji, u promatranom je razdoblju u kontinuiranom padu, dok je koeficijent starosti (postotak starog stanovništva $\geq 60$ godina u ukupnoj populaciji) u kontinuiranom porastu. To je jasan pokazatelj starenja stanovništva.

Već 1971. indeks starenja u Podgorju iznosio je 58, što je osjetno više od vrijednosti istog pokazatelja za Hrvatsku. Jasno je da je već tada stanovništvo Podgorja ušlo u proces demografskog starenja. Razmotre li se podatci ostalih popisa stanovništva uviđa se da je indeks starenja u kontinuiranom porastu. Tako je 2001. godine na 100 mladih dolazilo već 128,5 starih stanovnika. Prema posljednjem popisu stanovništva iz 2011. vrijednost indeksa starenja iznosila je 187,8 što ukazuje na jako uznapredovali proces demografskog starenja.

Kao pokazatelje starenja stanovništva možemo razmatrati i smanjenje predradnog i predfertilnog kontingenta stanovništva $\mathrm{s}$ jedne, te povećanje postradnog i postfertilnog kontingenta s druge strane. Posebno zabrinjava što je prema popisu iz 2011. samo $11,2 \%$ žena u ukupnoj populaciji Podgorja bilo u predfertilnoj dobi. Na temelju ovog pokazatelja može se reći da nije izgledna demografska obnova stanovništva Podgorja iz vlastitih demografskih resursa, te da je za poboljšanje postojećeg demografskog stanja potrebna imigracija mlađeg stanovništva u povoljnoj demoreproduktivnoj dobi. Potrebno je osmisliti sveobuhvatne mjere za smanjenje razine ostarjelosti stanovništva, a pri tome dodatni problem predstavlja činjenica da je najveći dio Podgorja u sastavu Ličko - senjske županije koja je hrvatska županija s najizraženijim problemskim karakteristikama, pa se postavlja pitanje je li ta županija uopće u stanju provoditi sve poželjne mjere bez značajne pomoći s državne razine. ${ }^{14}$

Tipizacija ostarjelosti po I. Nejašmiću (2003.) također jasno prikazuje progresiju starenja stanovništva. Prva tri promatrana popisa stanovništva prikazuju

${ }^{14}$ I. TURK, 2006, 499-515. 


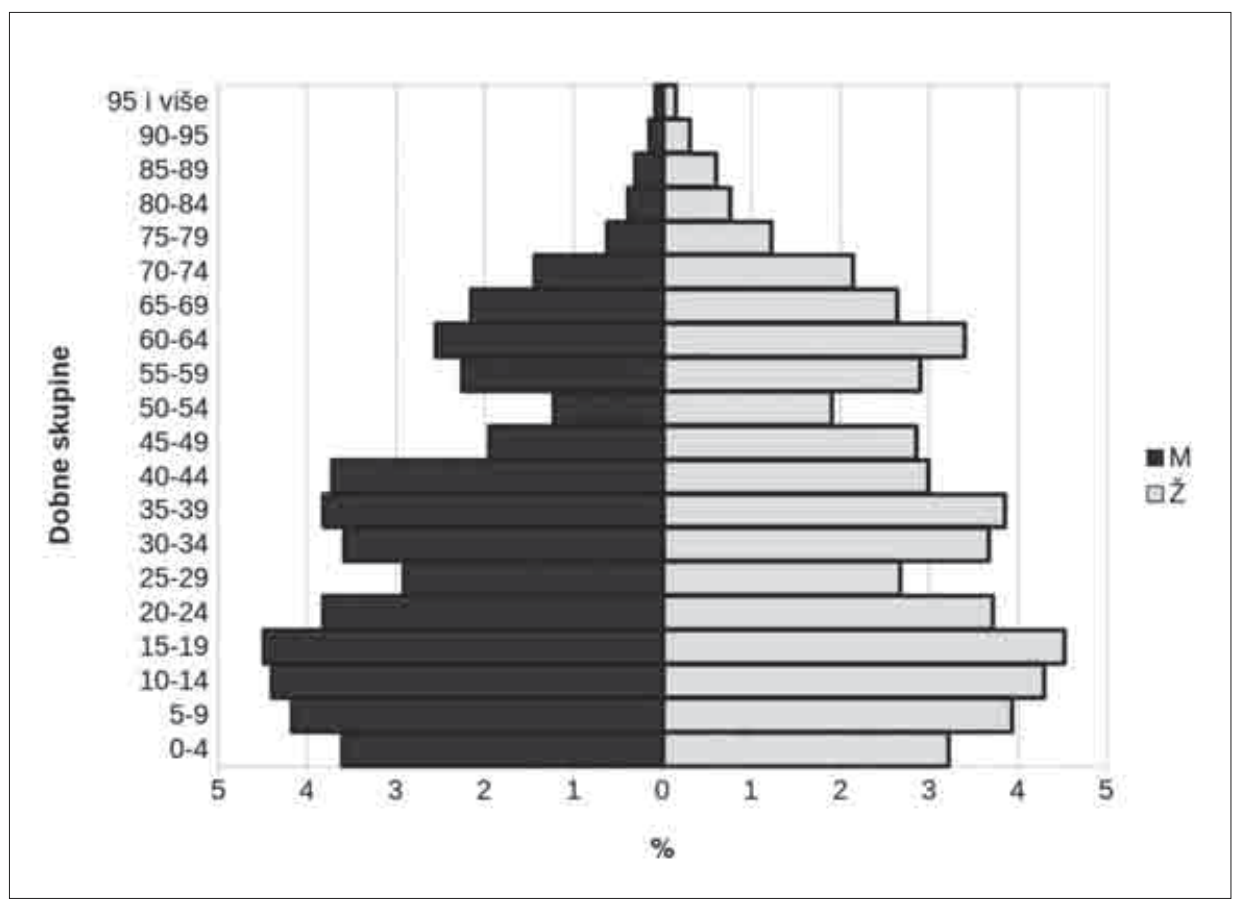

S1. 6. Sastav stanovništva prema dobi i spolu u Podgorju 1971. godine, izvor: Popis stanovništva i stanova 1971., Stanovništvo, Pol i starost - I deo, rezultati po naseljima i opštinama, Knjiga VIII, Savezni zavod za statistiku, Beograd, 1973.

tip 3 ostarjelosti čije je obilježje starost stanovništva. Promatramo li bodovne pokazatelje ostarjelosti uviđa se smanjenje njihove vrijednosti što označava progresiju procesa starenja. Posljednja dva promatrana popisa stanovništva prikazuju vrlo nepovoljan tip 5 ostarjelosti, čije je obilježje vrlo duboka starost populacije. Kontinuirano smanjenje bodovnog pokazatelja ostarjelosti prisutno je i tijekom najnovijeg promatranog međupopisja (2001. - 2011.).

Dobno-spolna piramida iz 1971. prikazuje dominaciju mlađih dobnih skupina, no već tada ima oblik kapi na kojemu primjećuje okrnjena baza najmlađih dobnih skupina, kao i demografski gubitci Prvog i Drugog svjetskog rata. Najbrojnija je dobna skupina starosti od 15 do 19 godina.

Četrdeset godina kasnije dobno-spolna piramida izgleda poput one iz 1971. zarotirane za $180^{\circ}$ (i ima oblik urne). Baza piramide je izrazito okrnjena, a najbrojnija je dobna skupina od 50 do 54 godina starosti. Ovakav sastav stanovništva prema dobi i spolu upućuje na produbljenje demografske krize u Podgorju. 


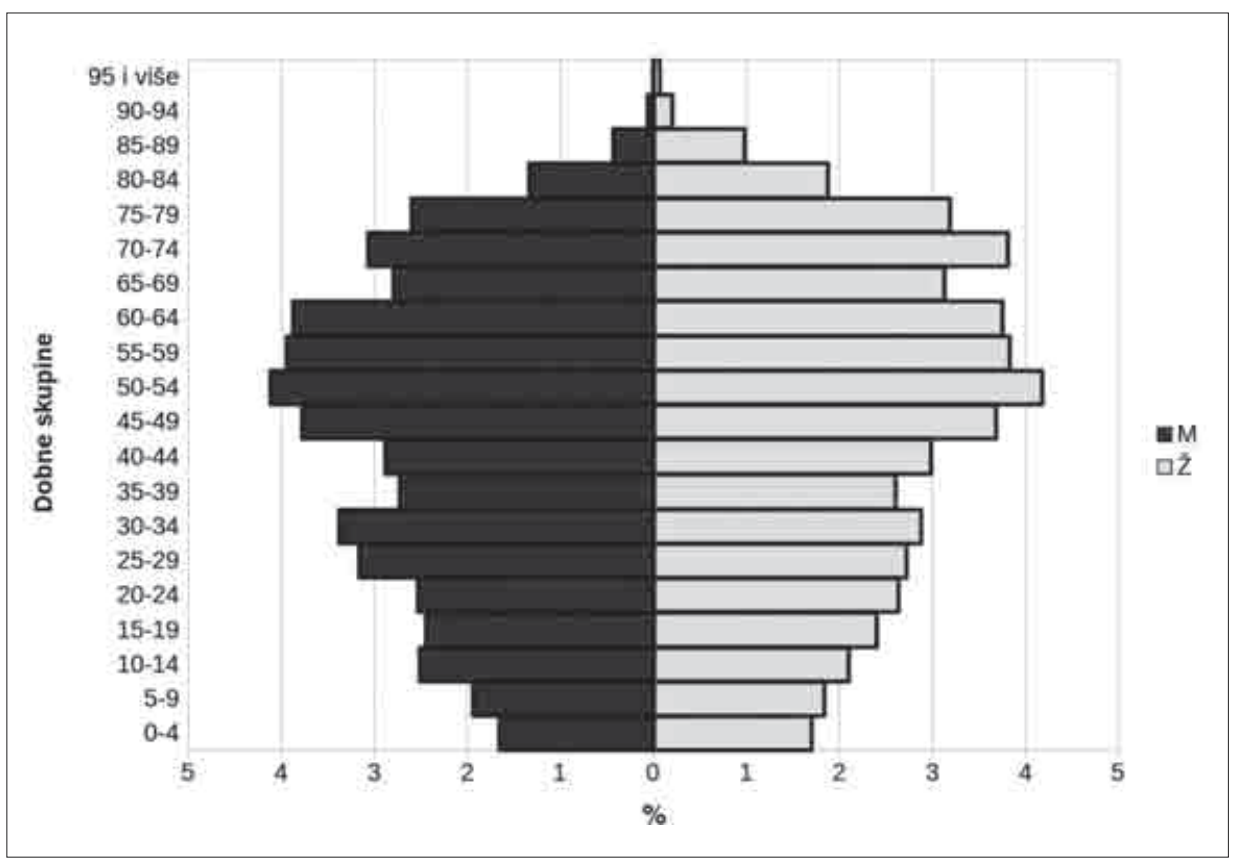

S1. 7. Sastav stanovništva prema dobi i spolu u Podgorju 2011. godine, izvor: www.dzs.hr (19. 12. 2016.)

Razmotri li se vrijednost indeksa starenja po podgorskim naseljima, prema najnovijem popisu stanovništva iz 2011., vidljivo je da je najveća koncentracija naselja s najnjepovoljnijom vrijednošću indeksa starenja u središnjem dijelu Podgorja koji je u sastavu Općine Karlobag. Već je ranije napominjano da karlobaški, odnosno središnji dio Podgorja ima općenito najnepovoljnije demografske pokazatelje. Razina ostarjelosti pri tome nije iznimka. Samo naselje Karlobag te njemu susjedna naselja imaju nešto bolje pokazatelje ostarjelosti, što se može objasniti centralnom ulogom Karlobaga u tom dijelu Podgorja. Već neposredno južno od Vidovca Cesaričkog, koji je susjedno naselje Karlobaga, nalazimo naselje Sušanj Cesarički koje 2011. uopće nije imalo mladog stanovništva i naselje Konjsko koje je prema popisu iz prethodno spomenute godine bilo bez stanovništva (izumrlo naselje). Već je ranije istaknuto da je ovaj dio Podgorja prometno najizoliraniji i tako izrazito nepovoljna demografska situacija se dobrim dijelom time može objasniti. Valja napomenuti da je prometna izolacija velikim dijelom fizičko-geografski (reljefno) uvjetovana. Sjeverni (senjski) dio Podgorja ima najmanje nepovoljnu razinu ostarjelosti. Ovdje se 


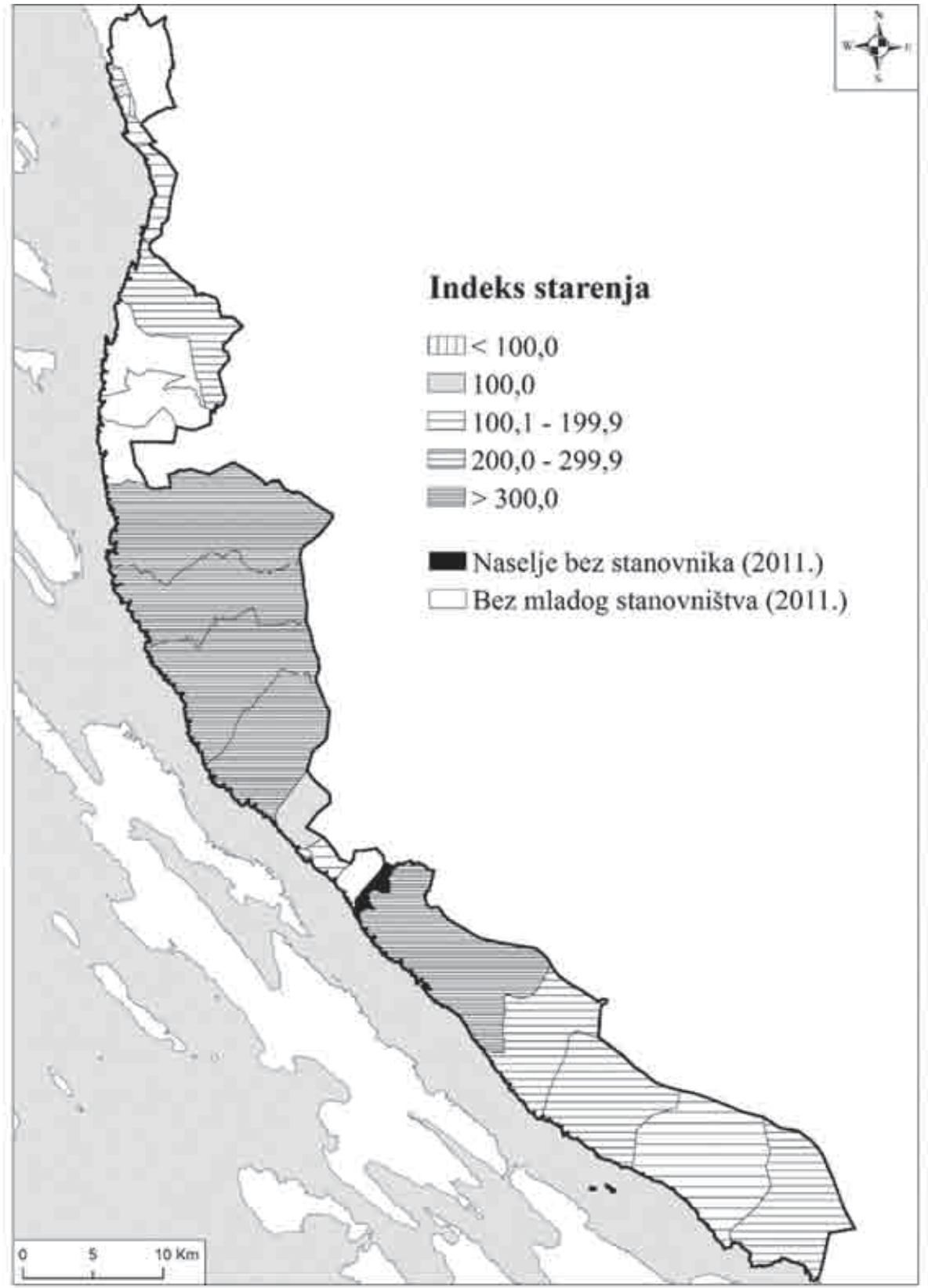

Sl. 8. Indeks starenja u podgorskim naseljima 2011. godine, izvor: www.dzs.hr (19. 12. 2016.) 
nalazi i naselje Pijavica koje je jedino 2011. imalo još uvijek više mladog nego starog stanovništva (indeks starenja 62,3). Južni (starigradski) dio Podgorja ima nepovoljnije pokazatelje ostarjelosti stanovništva od senjskog dijela, no ipak povoljnije od karlobaškog dijela.

\section{Zaključak}

Iz prikazanog je jasno da je Podgorje dio hrvatskog jadranskog priobalja (ne računajući pojedine otoke) s najnepovoljnijim demografskim pokazateljima. Ne postoji ni jedan dio hrvatskog kopnenog jadranskog priobalja koji ima toliko dug kontinuitet depopulacijskih procesa. Trend pada broja stanovnika (ukupna depopulacija) kontinuirano je prisutan od 1910. godine. Prirodni je pad broja stanovnika konstantan od 1988. godine, a migracijska bilanca i opće kretanje stanovništva je vrlo nepovoljno. Prirodni pad i emigracijski procesi rezultirali su intenzivnim starenjem stanovništva, pa je razina ostarjelosti u Podgorju osjetno veća od hrvatskog prosjeka.

Ovako nepovoljno stanje je ponajprije uzrokovano nepovoljnim fizičkogeografskim obilježjima, od kojih treba istaknuti reljef i klimu. Reljefni položaj na Velebitskoj primorskoj padini koja se relativno strmo spušta u more uvjetovao je manjak poljoprivredno obradivih površina, a izloženost buri koja nerijetko doseže i orkanske udare ne predstavlja pozitivan čimbenik za razvoj turizma. Uslijed nepovoljnih reljefnih čimbenika u Podgorju nije došlo do značajnijeg razvoja prometnica, a prometnu okosnicu čini Jadranska magistrala koja je izgradnjom modernih autocesta iz hrvatske unutrašnjosti prema moru djelomično izgubila na značaju.

U najvećem dijelu Podgorja nije bilo većih i značajnijih ekonomskih investicija koje bi generirale radna mjesta i na taj način omogućile zapošljavanje lokalnog stanovništva. Takva je situacija rezultirala emigracijom mlađeg stanovništva u najpovoljnijoj reproduktivnoj dobi.

Kombinacija nepovoljnih fizičko-geografskih i socijalno-geografskih čimbenika uvjetovala je sadašnju krajnje nepovoljnu demografsku situaciju. S obzirom na postojeće okolnosti, teško je u doglednoj budućnosti očekivati poboljšanje postojećeg demografskog stanja. Ne dođe li do provedbe sveobuhvatnih mjera demografskog i ekonomskog razvoja, izgledan je daljnji nastavak nepovoljnih demografskih procesa. Budući da je teško moguće da se mjere demografske obnove provedu iz vlastitih demografskih resursa, potrebno je razmisliti i o mjerama koje bi potakle imigraciju mlađeg stanovništva. 


\section{Literatura}

Mladen Ante FRIGANOVIĆ, Demogeografija - stanovništvo svijeta, Zagreb, 1990.

Dragica HUSANOVIĆ-PEJNOVIĆ, Demografski razvoj Podvelebitskog primorja u uvjetima periferije, Senjski zbornik, 37, Senj, 2010, 119-142.

Zoran KLARIĆ, Funkcija sjedišta županije i prometne veze kao čimbenici privlačnosti glavnih urbanih središta Hrvatske, Geoadria, 21, Zadar, 2016, 29-57.

Ivo NEJAŠMIĆ, Značajke biološkog (demogeografskog) sastava stanovništva Hrvatske, Hrvatski geografski glasnik, Vol. 65/2, Zagreb, 29-55, 2003.

Veljko ROGIĆ, Senj: Prilog poznavanju položaja i regionalne funkcije, Geografski glasnik, 14/15, 1952, 47-64.

Veljko ROGIĆ, Velebitska primorska padina: Prilog poznavanju evolucije krškog pejzaža II, Geografski glasnik, 20, Zagreb, 1958, 53-116.

Ivo TURK, Promjene u dobno-spolnom sastavu stanovništva Podvelebitskog primorja (1971. - 2001.), Akademik Josip Roglić i njegovo djelo, Zbornik radova, HGD, Split - Zadar - Zagreb, 2006, 499-515.

Alica WERTHEIMER-BALETIĆ, Stanovništvo i razvoj, MATE, Zagreb, 1999.

\section{Izvori podataka}

Popis stanovništva i stanova 1971., Stanovništvo, Pol i starost - I deo, rezultati po naseljima i opštinama, Knjiga VIII, Savezni zavod za statistiku, Beograd, 1973.

Popis stanovništva, domaćinstava, stanova i poljoprivrednih gospodarstava 31. ožujak 1991., Stanovništvo po spolu i starosti po naseljima, dokumentacija 882, Zagreb, 1994.

Tablogrami popisa stanovništva iz 1981., DZS, Zagreb

Tablogrami vitalne statistike (1971. - 2014.), DZS, Zagreb

www.dzs.hr (19.12.2016.) 


\section{CONTEMPORARY DEMOGRAPHIC FEATURES OF PODGORJE}

\section{Summary}

Podgorje encompasses the area of the Croatia Adriatic coast at the foot of Velebit. Viewed administratively, included in the research are the settlements of the town of Senj, plus the municipalities of Karlobag and Starigrad, which with their territory participate on the coast of the Adriatic Sea. The observed area is divided between Lika-Senj County (Town of Senj and the Municipality of Karlobag) and Zadar County (Municipality of Starigrad). Podgorje has very negative demographic features. The overall depopulation has lasted, with the exception of one intercensal period (1981-1991), continuously from 1910 when the largest population was noted $(16,782$ residents). In the following one hundred years the number of inhabitants almost halved. According to the latest census of the population from 2011 Podgorje had only 8,894 inhabitants. The natural depopulation has been present in Podgorje for many years, which influences the demographic conditions very negatively. The ageing of the population is in a very advanced stage. In 1971, the ageing index was 58, whilst according to the last census from 2011, the value of this demographic indicator had risen to as much as 187.8.

The reasons for this unfavourable demographic situation are complex. The physicalgeographical features have unfavourable affected development in the past (the karst relief with many steep configurations, and strong 'bura' wind). Today Podgorje is located in the zone of the overlapping nodal-functional regions of Rijeka, to which its northern part gravitates, and Zadar, to which its southern part gravitates. With the construction of the Zagreb-Split motorway and with the planned motorway or the Rijeka-Žuta Lokva express road, Podgorje will in effect find itself in a kind of transport-like isolation, which will not act favourably on the demographic and economic trends.

Despite the position on the Adriatic coast which offers the good possibility for the development of tourism, with the exception of Starigrad, where there is a starting point for trips into Paklenica National Park, this activity in Podgorje is not more significantly developed, which unfavourably affects the demographic conditions.

Keywords: Podgorje, overall depopulation, natural depopulation, ageing of the population, transport isolation 